\title{
Wind Energy Resource Map of Newfoundland
}

\author{
M. J. Khan, Graduate Student, Faculty of Engineering, MUN, St. John's, NL, Canada A1B3X5, \\ Ph: 709737 8809, Email: mjakhan@engr.mun.ca \\ M. T. Iqbal, Assistant Professor, Faculty of Engineering, MUN, St. John's, NL, Canada A1B3X5, \\ Ph: 709737 8934, Email: tariq@engr.mun.ca
}

\begin{abstract}
In this paper a wind resource map of Newfoundland is presented. A set of mesoscale wind maps, generated with the aid of NASA and NCEP/NCAR databases was studied for establishing a general pattern of wind speed variation throughout Newfoundland. Ground data from some key locations around Newfoundland is extrapolated for height and surface condition adjustments. By combining the modified ground data with one suitable global data based mesoscale map, a wind resource map indicating various classes of wind potential has been developed. It has been found that wind speed is generally higher in the coastal regions. Eastern Newfoundland, Northern Peninsula and Burin Peninsula have higher wind potential than the Avalon Peninsula and the western coast. Wind speed gradually increases from central Newfoundland towards the coasts. Several suggestions for further investigation and development of a complete wind map are also given.
\end{abstract}

\section{Introduction}

Two utility companies, Newfoundland Power (NP) and Newfoundland and Labrador Hydro (NLH) jointly deliver almost all the electricity demand of the province of Newfoundland and Labrador. Newfoundland has the majority of the customers and consumes about 1900 MW of electricity (2002). Most of the generation is either from hydroelectric or thermal (diesel or gas) power plants. Although distribution is mostly done through the island grid, there are many remote communities where diesel generators meet the demand. Most recent projections show that, existing system with some expansion could meet annual demand for the next 10 years. However, there are several long-term issues surrounding problems of existing generation and prospects of alternative sources of energy [1].

Hydroelectric plants, although pollutant free and cheaper to operate, require higher investment and affect the wildlife, fisheries and ecosystem adversely. Thermal power plants are cheaper to build, but have a shorter life span and emit various greenhouse gases. Wind energy, on the other hand possesses a good potential. In many parts of the world, wind energy has proven to be competitive against conventional sources. It has long been understood that Newfoundland has higher average wind speed than many other places in Canada. But progress towards harnessing energy from the wind has been slow. With only one wind turbine for feasibility study in St. Lawrence, the immense potential for generating electricity for the remote communities and exporting excess power to the mainland through submarine cable has remained unexplored [1].

The essential first step towards harnessing energy from the wind is to estimate the wind resources of a site under consideration. Although several reports [2,3] outlining wind potentials throughout Canada are available, these are of low resolution and involve initial assessments only (fig. 1). More comprehensive analysis for developing wind atlas is necessary for identifying potential sites for wind turbine installation and continuous economic operation.

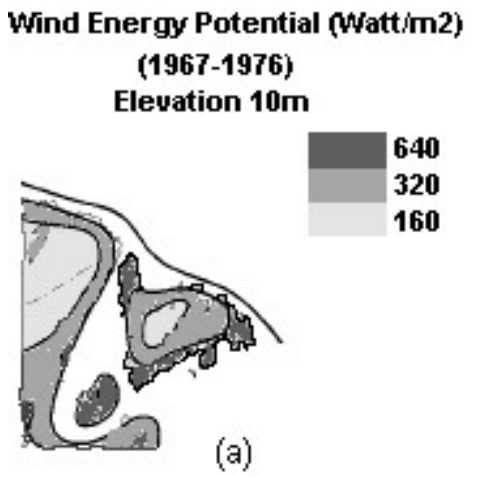

(a)

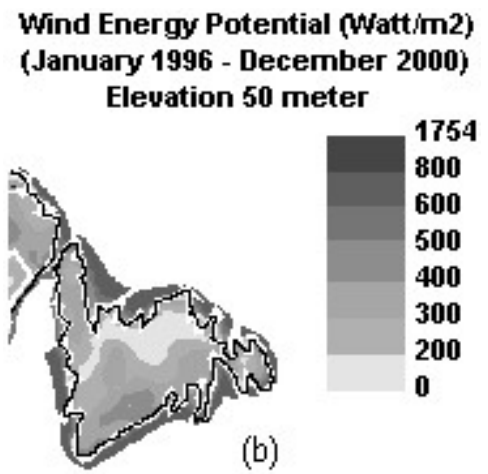

Figure 1: Reported wind maps of Newfoundland (a) Walmsley et al. [2] (b) EOLE Wind Energy Project [3]

In this paper, a wind resource map of Newfoundland with a better resolution is presented. Several global climatological databases were used in conjunction with a set of modified surface data to develop the wind map. Since, uncertainty in correlating the surface data with the mesoscale map appeared high, instead of indicating 
specific magnitudes of wind speed or power density, a general classification of wind resource is proposed. Commercial methods of developing wind maps such as MesoMap [4], or WAsP [5] are costly and may not be affordable to many. This assessment could be used as an alternative tool for pre-feasibility studies, identifying low/high wind areas or installing small-scale wind turbines.

\section{Developing a wind map}

Wind has three major classes of origin: primary, secondary and tertiary. The primary or global origin of wind resource is accounted for pressure differences across the earth's surface, effects of gravitational forces, air inertia, earth's rotation and surface friction. In a simpler form, four atmospheric forces: pressure force, Coriolis force (due to earth rotation), inertial force (due to global scale circular motion) and frictional forces (with the earth's surface) determine global perspective of wind motion (fig. 2). Secondary sources of wind include hurricanes, monsoon circulation and cyclones. Thirdly, diurnal variations, thunderstorms, tornadoes etc. determine short-term, small-scale wind variations [7].

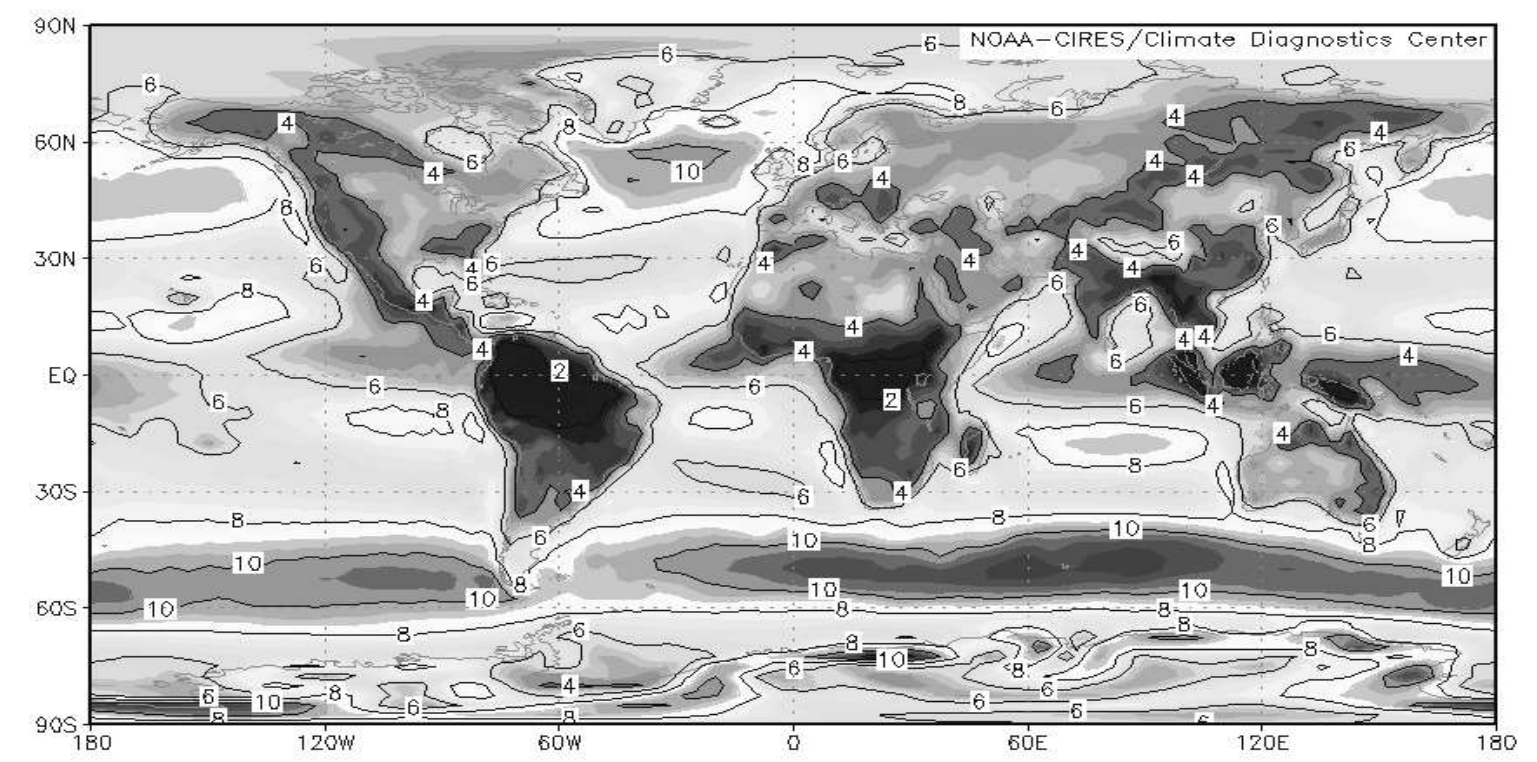

Figure 2: Overview of worldwide wind speed $(\mathrm{m} / \mathrm{s})$ variations at surface level. (CDC Derived NCEP Reanalysis Products-Surface Level, Averaged over Jan 1948 to Jun 2003) [8]

Assessing wind energy for a particular location is computationally demanding and time consuming. A long record (at least 5-10 year) of surface data collected with a dense measurement network is vital for such analysis. These data combined with global climatological databases and adjusted for terrain conditions, could produce a quality microscale wind map. However, in absence of one or more of these elements, an assessment is still possible with the aid of measure-correlate-predict (MCP) method [5,6]. According to this method, surface data from short measurements or sparsely located stations (low quality ground data) are correlated with the global databases, which yields a prediction of site-specific wind conditions.

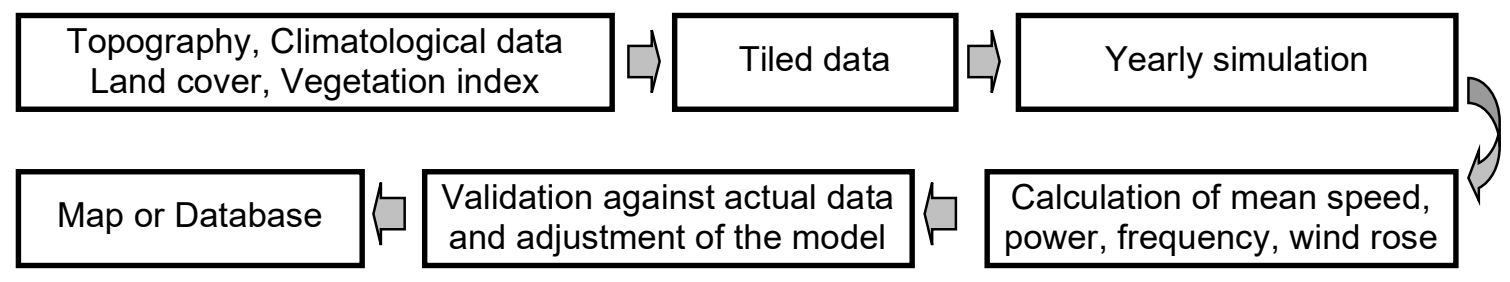

Figure 3: Conceptual block diagram of MCP method of wind map development

A mesoscale wind map shows wind variations throughout a large area $(50 \sim 100 \mathrm{~km}$ resolution) neglecting the local effects such as orography, obstacles, surface roughness and thermally driven flows. Using statistical dynamical 
approaches large-scale global climatological data can be used in that regard. A microscale map, which is the ultimate goal towards selecting suitable wind sites, incorporates features such as, terrain conditions, roughness, land cover, vegetation, elevation etc. to the mesoscale map. In this paper, a mesoscale map generated with global climatological data, is investigated with a set of ground data for classifying Newfoundland's wind resources. Although not truly a microscale map, this work would be useful in making general assessments. Introduction of surface conditions with extensive details remains for later investigations.

\section{Wind map with global databases}

Newfoundland is situated between $46^{\circ} 30^{\circ} \mathrm{N}$ to $51^{\circ} 30^{\circ} \mathrm{N}$ and $52^{\circ} 30^{\prime} \mathrm{W}$ to $59^{\circ} 30^{\circ} \mathrm{W}$. Being a maritime province its climate is strongly affected by the Atlantic Ocean. A worldwide wind atlas generated with NOAA/CIRES-Climate Diagnostic Center's (CDC) search engine (NCEP reanalysis product), reveals that the surface mean wind speed over Newfoundland is within the range of 6 to $8 \mathrm{~m} / \mathrm{s}$ (Fig. 2) [8]. A set of wind maps with better resolution $\left(1^{\circ}\right.$ by $1^{\circ}$ block) is investigated below to select a suitable map for further analysis.

\subsection{Wind map using NASA-SSE database}

National Aeronautics and Space Administration's (NASA) Surface meteorology and Solar Energy (SSE) data set maintained in collaboration with the CAMNET Energy Technology Center is an excellent source of renewable energy data $[9,10]$. The data from this site could be used in conjunction with the RETScreen ${ }^{\circledR}$ International Renewable Energy Project Analysis Software [10]. These data are a consistent 10-year global average on a $1^{\circ}$ by $1^{\circ}$ (about $100 \mathrm{~km}$ by $100 \mathrm{~km}$ ) grid. The SSE data,which is essentially an average over the entire area of the cell may not represent a particular site within the grid. However, this database is an excellent and easy-to use source which could be used for preliminary studies of renewable energy systems.

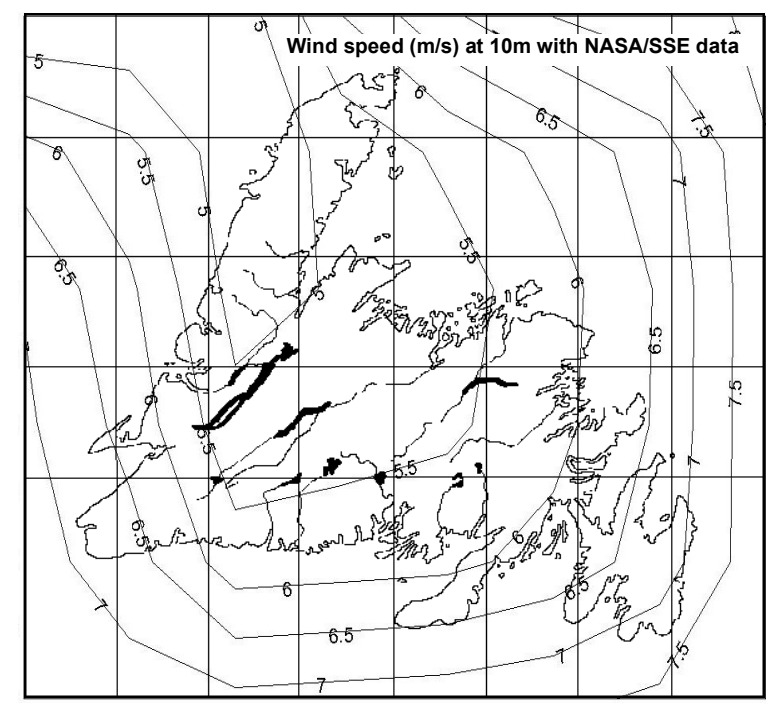

(a)

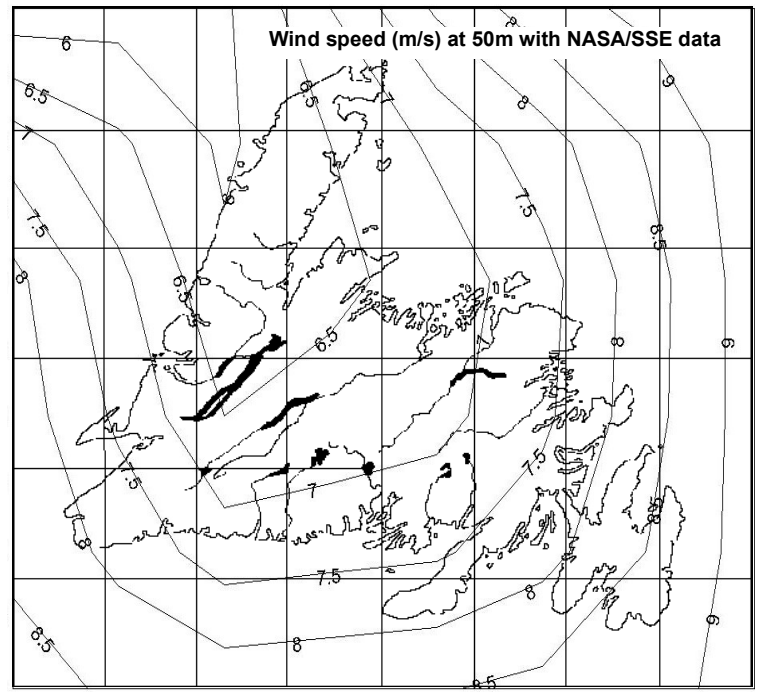

(b)

Figure 4: Wind map (m/s) of Newfoundland using NASA-SSE-data set (a) 10m height (b) 50m height

Two sets of wind speed data for $10 \mathrm{~m}$ and $50 \mathrm{~m}$ heights were gathered for $46^{\circ} 30^{\circ} \mathrm{N}$ to $51^{\circ} 30^{\prime} \mathrm{N}$ and $52^{\circ} 30^{\prime} \mathrm{W}$ to $59^{\circ} 30^{\prime} \mathrm{W}$. These data after rearranging in a 6 by 8 matrix (48 data points, each for one $1^{\circ}$ by $1^{\circ}$ grid), were used in Matlab [11] to create the contour plots shown in fig. 4. These models assume airport like terrain conditions with little near-by obstacles. At $10 \mathrm{~m}$ height, the wind speed varies from 5 to $7.5 \mathrm{~m} / \mathrm{s}$ from the west to the east. At $50 \mathrm{~m}$ level, the variation is elevated to 6 to $8.5 \mathrm{~m} / \mathrm{s}$.

\subsection{Wind map using NOAA/CIRES-CDC database}

The Climate Diagnostic Center (CDC) database maintained by the National Oceanic and Atmospheric Administration (NOAA) and the Cooperative Institution for Research and Environmental Sciences (CIRES) is 
another comprehensive source of weather and climatological information. The search mechanism in CDC allows one to collect a wide range of climate data from many different sources. After analyzing a collection of several wind maps generated with CDC's databases, two significant wind models were chosen (NCEP/NCAR Reanalysis and COADS 2 deg. std).

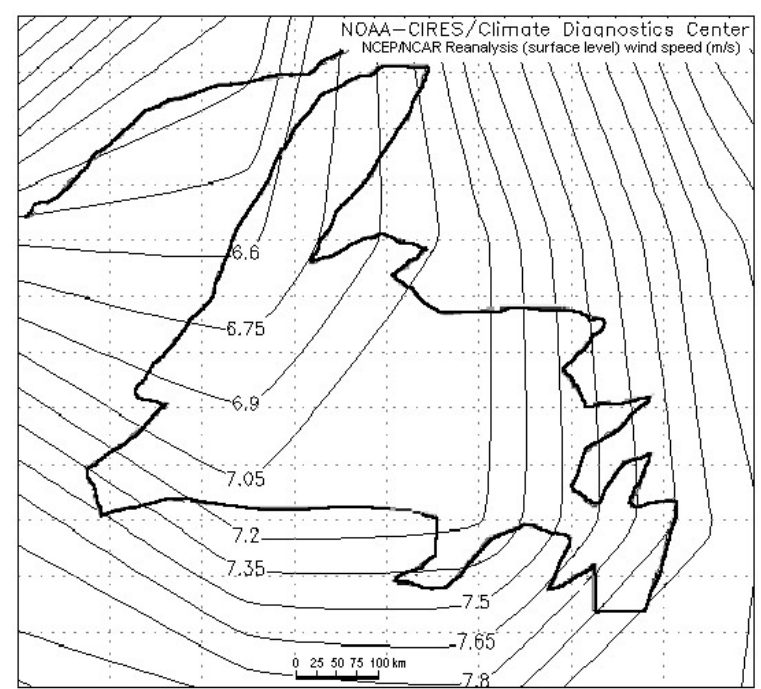

(a)

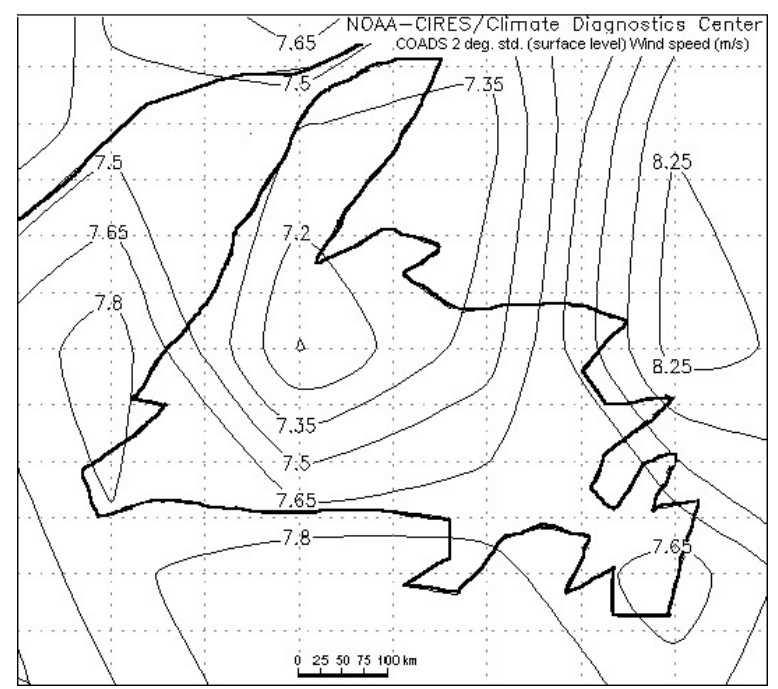

(b)

Figure 5: Wind map of Newfoundland at surface level (m/s) (a) CDC Derived NCEP Reanalysis Product averaged over Jan 1948 to Aug 2003 (b) COADS (2 deg. standard) data averaged over Jan 1800 to Dec 1997

The NCEP/NCAR (National Center for Environmental Prediction/National Center for Atmospheric Research) Reanalysis project performs analysis of weather data from 1948 to the present using comprehensive methods of atmospheric modeling and forecasting. A surface level wind map of Newfoundland is given in fig. 5(a) using NCEP Reanalysis data. It indicates that surface level wind varies from 6 to $8 \mathrm{~m} / \mathrm{s}$, increasing gradually from the west to the east coast.

The Comprehensive Ocean-Atmosphere Data Set (COADS) is an extensive collection of worldwide surface marine data gathered over the past two centuries. The basic observed variables by COADS include sea surface and air temperatures, wind, humidity etc. The observations are gridded for $2^{\circ}$ by $2^{\circ}$ tiles (1854 to 1995), and for $1^{\circ}$ by $1^{\circ}$ tiles (1960-onward). Close proximity of Newfoundland to the Atlantic Ocean and its interactions with the marine climate make the COADS analysis suitable to a great extent. Fig. 5(b) shows a surface level wind map generated with COADS. Unlike the other models (fig. 4, fig. 5(a)), this plot shows pockets of higher and lower wind areas within the island.

\section{Ground data extrapolation}

Correlation of global climatological database with systematically collected, quality ground data containing information of wind speed, direction, turbulence intensity etc. is the de facto standard for wind map generation. Wind data measured at low tower height having near-by obstacles such as hills, tall tress, houses etc. are generally downwardly biased and contain higher turbulence and lower power concentration. Since surface measurement is generally done at various tower heights and dissimilar surrounding conditions (hills, vegetation, elevation, obstacles, water body etc.), standardization of these data is necessary for further analysis.

The variation of wind speed with elevation could be modeled with the power law $[2,4,7]$ :

$$
U_{z}=\left(\frac{Z}{Z_{t}}\right)^{\alpha} U_{t}
$$


Here, $U_{t}$ is the wind speed at tower height $Z_{t}$, and $U_{z}$ denotes the extrapolated value of wind speed at $Z$ height. The power law exponent (shear exponent) $\alpha$, varies with parameters such as elevation, time of day, season, terrain, temperature, wind etc. and takes into account the near-by terrain conditions.

The uncertainty involved with such modeling could be determined by two factors, tower height and length of record. As the modified height gets closer to the original tower height, error in such prediction decreases. Similarly, data averaged over a long record is more reliable and of less uncertainty. A model of percentage error could be given as [12]:

$$
e=100 \times \sqrt{\left(\left(\frac{Z}{Z_{t}}\right)^{0.15 \alpha}-1\right)^{2}+\left(\frac{0.06}{\sqrt{N}}\right)^{2}}
$$

Here, $N$ is the number of year of observation.

\begin{tabular}{|c|c|c|c|c|c|c|c|c|c|c|}
\hline$\#$ & Station & Lat. & Long. & $\begin{array}{c}\text { Tower } \\
\text { Height }\end{array}$ & $\begin{array}{c}\text { Years of } \\
\text { record }\end{array}$ & $\begin{array}{c}\text { Wind Speed } \\
(\mathbf{m} / \mathbf{s})\end{array}$ & Direction & $\begin{array}{c}\text { Wind speed } \\
\text { at 10m(m/s) }\end{array}$ & $\begin{array}{c}\text { \% Error } \\
\text { Wind speed at } \\
\mathbf{5 0 m}(\mathbf{m} / \mathbf{s})\end{array}$ & $\begin{array}{c}\text { \% } \\
\text { Error }\end{array}$ \\
\hline 1 & Gander Int'l A & $48^{\circ} 57^{\prime}$ & $54^{\circ} 34^{\prime}$ & $151 \mathrm{~m}$ & 1937 to 1990 & 5.7697 & W-SW & 3.9152 & 5.71 & 4.9272 \\
\hline 2 & Bonavista & $48^{\circ} 40^{\prime}$ & $53^{\circ} 07^{\prime}$ & $25 \mathrm{~m}$ & 1956 to 1990 & 8.2913 & SW-W & 8.5088 & 2.19 & 9.1529 \\
\hline 3 & Burgeo & $47^{\circ} 37^{\prime}$ & $57^{\circ} 37^{\prime}$ & $12 \mathrm{~m}$ & 1966 to 1990 & 6.4749 & E-W & 6.3085 & 1.26 & 7.9393 \\
\hline 4 & Comfort Cove & $49^{\circ} 16^{\prime}$ & $54^{\circ} 53^{\prime}$ & $96 \mathrm{~m}$ & 1967 to 1990 & 5.2141 & SW & 3.7745 & 4.89 & 4.7502 \\
\hline 5 & Arnolds Cove & $47^{\circ} 45^{\prime}$ & $54^{\circ} 00^{\prime}$ & $15 \mathrm{~m}$ & 1971 to 1990 & 3.9533 & W & 3.7308 & 1.60 & 4.6952 \\
\hline 6 & Deer Lake A & $49^{\circ} 13^{\prime}$ & $57^{\circ} 24^{\prime}$ & $16 \mathrm{~m}$ & 1965 to 1990 & 4.4021 & SW-NE & 4.1143 & 1.55 & 5.1778 \\
\hline 7 & $\begin{array}{c}\text { Port Aux } \\
\text { Basques }\end{array}$ & $47^{\circ} 34^{\prime}$ & $59^{\circ} 10^{\prime}$ & $40 \mathrm{~m}$ & 1909 to 1990 & 6.4962 & W-E & 5.3291 & 3.00 & 6.7064 \\
\hline 8 & St John's A & $47^{\circ} 37^{\prime}$ & $52^{\circ} 44^{\prime}$ & $134 \mathrm{~m}$ & 1942 to 1990 & 6.6458 & W-SW & 4.5870 & 5.48 & 5.7728 \\
\hline 9 & St Lawrence & $46^{\circ} 55^{\prime}$ & $55^{\circ} 23^{\prime}$ & $46 \mathrm{~m}$ & 1966 to 1990 & 7.1160 & W-SW & 5.7253 & 3.43 & 7.2053 \\
\hline 10 & Stephenville A & $48^{\circ} 32^{\prime}$ & $58^{\circ} 33^{\prime}$ & $8 \mathrm{~m}$ & 1942 to 1990 & 4.8936 & W & 5.0521 & 0.98 & 6.352 \\
\hline 11 & $\begin{array}{c}\text { Daniels } \\
\text { Harbour }\end{array}$ & $50^{\circ} 14^{\prime}$ & $57^{\circ} 35^{\prime}$ & $18 \mathrm{~m}$ & 1946 to 1990 & 6.6245 & SW & 6.0910 & 1.54 & 7.21 \\
\hline
\end{tabular}

Table 1: Wind speed data $(\mathrm{m} / \mathrm{s})$ from weather stations and extrapolated values at $10 \mathrm{~m}$ and $50 \mathrm{~m}$ heights

A set of ground data from 11 locations around Newfoundland is collected from Environment Canada's climate normals [13]. Extrapolated wind speed at $10 \mathrm{~m}$ and $50 \mathrm{~m}$ is given in table 1, along with the corresponding percentage of uncertainty. Terrain conditions of the weather stations could not be identified. Therefore, the value of shear exponent $\alpha$ is taken to be $1 / 7$ as a rule of thumb $[2,4,7]$ while using equations 1 and 2 .

\section{Wind resource classification}

The mesoscale wind maps (fig. 4 and fig.5) show general patterns of wind speed variation. The NASA/SSE models (fig. 4) and NCEP/NCAR Reanalysis (fig. 5(a)) indicate similar variation (increasing from west to east). However, a comparison of the standardized wind data (table 1) reveals that such progressive variation may not be accurate. The COADS model (fig. 5(b)), on the other hand shows some pockets of high (mainly coastal) and low wind (mostly inland) areas, which are generally backed up by the modified surface data.

The COADS data based wind map could therefore be downscaled to fit the terrain conditions, elevation, vegetation, land cover etc. and a microscale map could be found. The surface wind speed shown in the map (fig. 5(b)) would essentially decrease when factors such as obstacles, orography, and surface roughness are taken into account. A standardization of that microscale surface data to $10 \mathrm{~m}$ or $50 \mathrm{~m}$ elevations would produce a suitable wind map. But, such a scheme requires extensive geophysical modeling, statistical analysis and fluid dynamic investigations. Therefore, an alternative approach is adopted in this paper. 
The COADS map shows a good match with the standardized surface data (in terms of higher or lower winds) but fails to confirm the magnitude of the wind speeds. Therefore, this map could be taken as a base map and a range (instead of a specific value) of wind speed could be attributed to each of the contour lines. Such a map essentially incorporates a lower and higher wind speed limit for each of the regions. For example, the innermost contour in fig. 5(b) (marked as $7.2 \mathrm{~m} / \mathrm{s}$ ), contains the Deer Lake ground data site. Since the standardized wind speed for that location is $4.1 \mathrm{~m} / \mathrm{s}$ at $10 \mathrm{~m}(5.2 \mathrm{~m} / \mathrm{s}$ at $50 \mathrm{~m})$, a contour could be drawn within the $7.2 \mathrm{~m} / \mathrm{s}$ line, to indicate a region of 0 to $4.4 \mathrm{~m} / \mathrm{s}$ wind at $10 \mathrm{~m}$ elevation (class 1, table 2). Such intervals of wind speed and corresponding power density are being widely used for classifying wind resources $[14,15]$. A chart of wind speed/power density classes used in the United States is followed here (table 2) [14].

\begin{tabular}{|c|c|c|c|c|}
\hline \multirow[b]{2}{*}{$\begin{array}{l}\text { Wind } \\
\text { Power } \\
\text { Class }\end{array}$} & \multicolumn{2}{|c|}{ Height $(10 \mathrm{~m})$} & \multicolumn{2}{|c|}{ Height $(50 \mathrm{~m})$} \\
\hline & $\begin{array}{l}\text { Power } \\
\text { Density } \\
\left(\mathrm{W} / \mathrm{m}^{2}\right)\end{array}$ & $\begin{array}{l}\text { Wind } \\
\text { Speed } \\
(\mathrm{m} / \mathrm{s})\end{array}$ & $\begin{array}{l}\text { Power } \\
\text { Density } \\
\left(\mathrm{W} / \mathrm{m}^{2}\right)\end{array}$ & $\begin{array}{l}\text { Wind } \\
\text { Speed } \\
(\mathrm{m} / \mathrm{s})\end{array}$ \\
\hline 1 & 0 & 0 & 0 & 0 \\
\hline & 100 & 4.4 & 200 & 5.6 \\
\hline 3 & 150 & 5.1 & 300 & 6.4 \\
\hline \multirow{2}{*}{4} & 200 & 5.6 & 400 & 7.0 \\
\hline & 250 & 6.0 & 500 & 7.5 \\
\hline 5 & 300 & 6.4 & 600 & 8.0 \\
\hline \multirow{2}{*}{7} & 400 & 7.0 & 800 & 8.8 \\
\hline & 1000 & 9.4 & 2000 & 11.9 \\
\hline
\end{tabular}

*Vertical extrapolation of wind speed based on the 1/7 power law.

Table 2: Wind power classes

Using a mesoscale map for developing a wind atlas without considerations for the geophysical structure of a region is erroneous. Therefore, each of the regions in the COADS wind model could be given a lower and upper wind speed limit after comparing it with standardized wind speeds of table 1. Identification of higher and lower wind areas and their relative positions in the mesomap are also necessary in that regard. A wind resource map with power density classes from 1 to 7 is shown in fig. 6(b). A comparison with the modified ground data (fig. 6(a)) shows that the proposed wind map has a good match. However, places such as Comfort Cove, Gander Int'l Airport and St. John's show some deviation probably due to insufficiency of terrain modeling. This wind map could also be verified against the previous works (fig. 1) where similar pattern of wind resource could be seen (lower in central Newfoundland and higher around the coasts).

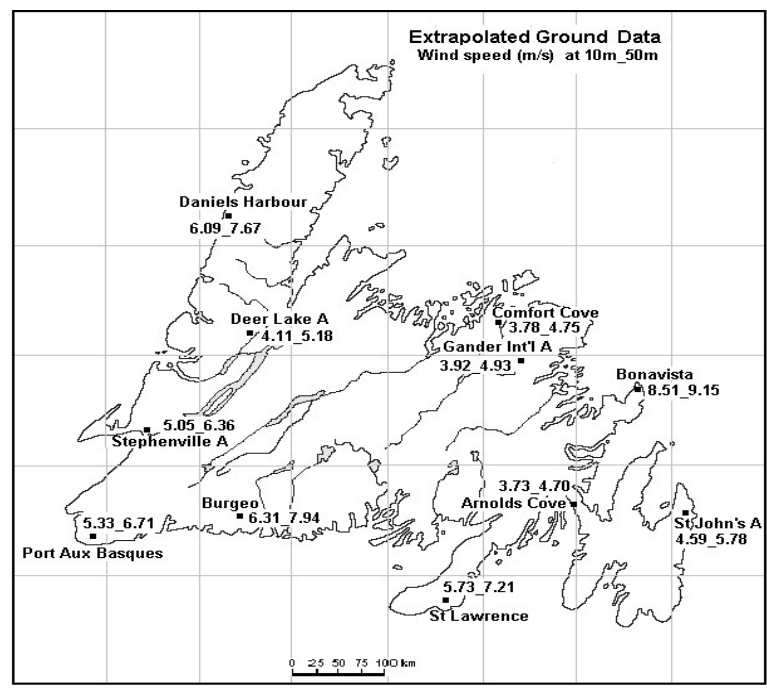

(a)

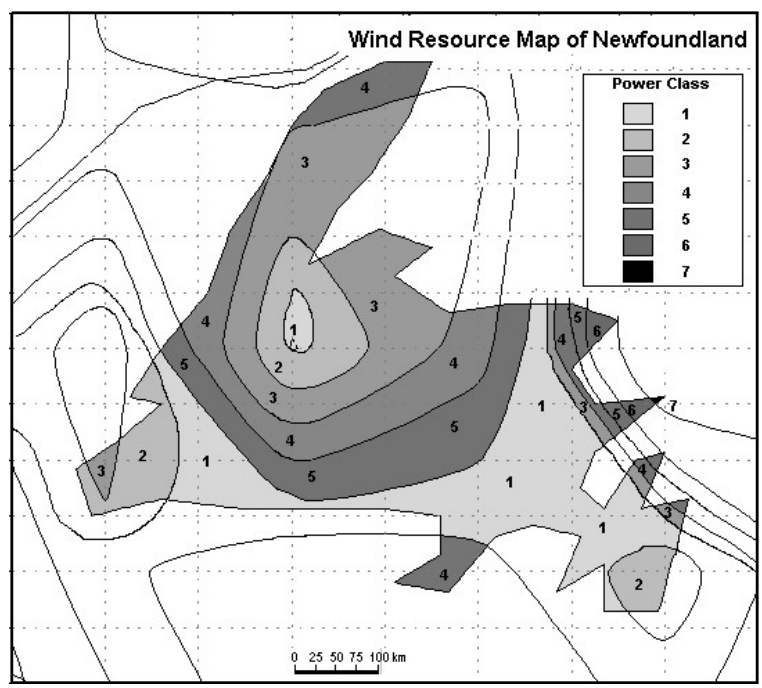

(b)

Figure 6: (a) Standardized wind speed $(\mathrm{m} / \mathrm{s})$ at $10 \mathrm{~m}$ an $\mathrm{d} 50 \mathrm{~m}$ elevations (b) Wind resource map of Newfoundland

A number of reasons may cause significant deviations from the proposed model. Firstly, only one type of terrain condition is considered during standardization (shear exponent, $\alpha$ is taken to be 1/7 as a rule of thumb), which is 
certainly not true for all the measurements sites. Secondly, data from a weather station is assigned to a very wide region. Wind speed varies significantly from one place to another due to various microscale features such as hills, mountains, lakes, rivers, forests, vegetation etc. Generalization of weather data over a wide area is therefore inadequate in making a microscale wind map $[2,5,6]$.

Further works may include geophysical characterization, fluid dynamic analysis and statistical modeling. Seasonal variations such as snow-cover, vegetation, temperature etc. should also be investigated for a more comprehensive assessment.

\section{Conclusion}

A wind resource map of the island of Newfoundland with better resolution than previous reports is presented. By combining a mesoscale map with a set of standardized ground data, wind resource throughout the island is classified into seven categories. It has been found that the Bonavista Bay region has the most promising wind potential (300 $\sim 1000$ watt $/ \mathrm{m}^{2}$ at $10 \mathrm{~m}$ elevation). The Burin and Northern Peninsula have medium wind resources with a power density of $150 \sim 250$ watt $/ \mathrm{m}^{2}$ at $10 \mathrm{~m}$ hub height. Wind speed in the Avalon Peninsula varies from $4.5 \sim 6 \mathrm{~m} / \mathrm{s}$ at $10 \mathrm{~m}$ heights and this region has relatively lower potential. In general, wind speed increases from central Newfoundland towards the coastal regions. Selection of suitable sites for installation of wind turbines and cost effective operation would require further analysis along with geophysical and meteorological modeling. Until then, this model could be used for small-scale installations and feasibility studies.

\section{References}

[1] Department of Mines and Energy, An Electricity Policy for the 21st Century: Options \& Opportunities. Energy Branch, Government of Newfoundland and Labrador, Natural Resources Building, 50 Elizabeth Avenue, St. John's, NL, A1A 1W5, March 2002, URL: http://www.gov.nl.ca/mines\&en/industry/overview.stm

[2] Walmsley J.L, Morris R.J, Wind Energy Resource Maps for Canada, Atmospheric Environment Service, Environment Canada, Report ARD-92-003-E, October 23, 1992.

[3] EOLE Wind Energy Project; MSC/RPN Project for Wind Energy Resource and Prediction, Environment Canada, October 2002. URL: http://www.cmc.ec.gc.ca/rpn/modcom/eole

[4] Brower M., Bailey B., Zack J., Micrositing Using the Mesomap System, , TrueWind Solutions, LLC, 251 Fuller Road, Albany, New York USA 12203 URL: http://www.truewind.com/

[5] Landberg L., Myllerup L., Rathmann O., Petersen E. L., Jorgensen B. H., Badger J., Mortensen N. G, Wind Resource Estimation - An Overview, Wind Energy, Volume 6, Issue 3, pp.261-271, 2003.

[6] Petersen E.L., Mortensen N.G., Landberg L.,Hojstrup J.,Frank H.P., Wind Power Meteorology, Wind Energy Department, December 1997, Risø National Laboratory, Frederiksborgvej 399, P.O. 49, DK-4000 Roskilde. URL: http://www.risoe.dk/

[7] Manwell J.F., McGowan J.G., Rogers A.L., Wind Energy Explained, John Wiley \& Sons Ltd, West Sussex, England, ISBN 0-471-49972-2, 2002

[8] NOAA-CIRES Climate Diagnostics Center: 325 Broadway, R/CDC1, Boulder, CO 80305-3328. URL: www.cdc.noaa.gov

[9] NASA, SSE database. URL: http://eosweb.larc.nasa.gov/sse/RETScreen/

[10]CAMNET Energy Technology Center, RETScreen ${ }^{\circledR}$ International Renewable Energy Project Analysis Software. URL: http://www.retscreen.net/

[11] The MathWorks, Inc., 3 Apple Hill Drive, Natick, MA 01760-2098,US, URL: http://www.mathworks.com/

[12] Wind Energy Resource Maps of the Republic of Ireland, February 2003, TrueWind Solutions, LLC, Albany, New York, USA 12203 URL: http://www.truewind.com/

[13] Canadian Climate Normals, 1961-1990, Canadian Climate and Water Information, Environment Canada, , 45 Alderney Drive, Dartmouth, Nova Scotia B2Y 2N6,

URL: http://www.msc-smc.ec.gc.ca/climate/climate_normals_1990/index_e.cfm

[14] Bergey Wind Power Co., 2001 Priestley Ave., Norman, Ok 73069 USA, URL: http://www.bergey.com/wind_maps.htm

[15] Renewable Resource Data Center (RReDC), National Renewable Energy Laboratory (NREL), 1617 Cole Boulevard, Golden, CO 80401-3393. URL: http://rredc.nrel.gov/ 